\title{
The storage of cow eggs at room temperature and at low temperatures
}

\author{
A. O. Trounson, S. M. Willadsen, L. E. A. Rowson and R. Newcomb \\ A.R.C. Unit of Reproductive Physiology and Biochemistry, Cambridge, U.K.*
}

\begin{abstract}
Summary. The survival and development of cow eggs in the rabbit oviduct after storage at room temperature and after cooling and storage at $0-7 \cdot 5^{\circ} \mathrm{C}$ was examined. In PBS medium at room temperature $88 \%$ of Day-5 and $85 \%$ of Day-3 eggs showed normal development, but in TCM 199, $71 \%$ of Day- 5 and only $49 \%$ of Day-3 eggs showed normal development. Duration of storage $\left(1 \frac{1}{2}-2 \mathrm{hr}\right.$ or $\left.6 \frac{1}{2}-7 \frac{1}{2} \mathrm{hr}\right)$ and cleavage stage before storage had no appreciable effect on development. Some retardation of development occurred in Day-3 eggs after $96 \mathrm{hr}$ in the rabbit oviduct when compared to Day-5 eggs after $48 \mathrm{hr}$. Cooling of Day-5 and Day-6 eggs to $0-7 \cdot 5^{\circ} \mathrm{C}$ resulted in degeneration of a large proportion of eggs. Of the factors examined, storage medium (PBS or PBS $+20 \%$ FCS), storage time ( $2 \mathrm{~min}, 30 \mathrm{~min}, 24 \mathrm{hr}$ ) and storage temperature $\left(0,2,5\right.$ or $\left.7.5^{\circ} \mathrm{C}\right)$ had little effect, but slower cooling rates tended to improve survival of eggs although the differences were not significant. More morulae ( $>32$ cells) than 8- to 24-celled eggs developed normally.
\end{abstract}

\section{Introduction}

Surgical egg transfer in the cow requires storage of eggs in vitro for several hours, particularly when many eggs are recovered from a single donor. Other treatments, such as freezing and micro-manipulation, also depend on the retention of full viability of eggs at room temperature for short periods of time. It is therefore important to define conditions which allow fertilized cow eggs to retain their full viability during short-term storage in vitro. In the experiments of Rowson, Moor \& Lawson (1969) and Rowson, Lawson \& Moor (1971), eggs were generally stored for less than $2 \frac{1}{2} \mathrm{hr}$ before transfer to recipients but a small number of eggs was stored in TCM 199 for up to $4 \frac{1}{2} \mathrm{hr}$ and some continued to develop after transfer. However, Sreenan, Beehan \& Mulvehill (1975) found that storage of cow eggs beyond $2 \mathrm{hr}$ in TCM 199 resulted in a marked reduction of embryo survival on transfer to recipients.

Storage of eggs during arrested development beyond a few hours probably requires cooling or deep-freezing of eggs. In this respect, the preservation of viability after cooling is an essential prerequisite for successful storage of eggs at low temperatures. Sreenan, Scanlon \& Gordon (1970) reported limited development of 4- to 10 -celled cow eggs stored for $20-24 \mathrm{hr}$ at $10^{\circ} \mathrm{C}$. However, Wilmut, Polge \& Rowson (1975) found that 8-celled cow eggs failed to survive cooling to $0^{\circ} \mathrm{C}$ whereas morulae survived cooling to $0^{\circ} \mathrm{C}$ for $15 \mathrm{~min}$. Only a few eggs were used in these experiments and attempts to freeze morulae were unsuccessful.

The present experiments were carried out to study the survival of cow eggs stored at room temperature for periods up to $6 \frac{1}{2}$ or $7 \frac{1}{2} \mathrm{hr}$ and to examine the survival of cow eggs after cooling and cold storage at temperatures ranging from $0^{\circ} \mathrm{C}$ to $7 \cdot 5^{\circ} \mathrm{C}$.

\section{Materials and Methods}

Hereford, Friesian and Hereford $\times$ Friesian heifers were used to provide fertilized eggs. Superovulation was induced by a single injection of 2000 i.u. PMSG (Folligon: Intervet) and the time of

* Postal address: Animal Research Station, 307 Huntingdon Road, Cambridge, U.K. 
oestrus was controlled by an intramuscular injection of $1000 \mu \mathrm{g}$ prostaglandin analogue $(80,996$ : I.C.I.), given $48 \mathrm{hr}$ after PMSG. Most heifers were detected in oestrus $48 \mathrm{hr}$ after the prostaglandin injection and were inseminated once with freshly collected bull semen.

Eggs were obtained from donor heifers on Days 3, 5 or 6 (Day $0=$ day of oestrus), using the methods of Rowson et al. (1969) with minor modifications. The medium used to flush eggs from the oviducts and uterine horns was either Tissue Culture Medium 199, based on Hanks' salts and containing $\mathrm{NaHCO}_{3}$ (TCM 199: B.D.H.) or Dulbecco's phosphate-buffered saline (PBS) prepared as described by Whittingham (1971).

\section{Experiment 1}

The storage at room temperature $\left(18-21^{\circ} \mathrm{C}\right)$ of Day-3 and Day-5 eggs in TCM 199 and PBS was examined. The fertilized eggs from 10 heifers on Day 3 and 9 heifers on Day 5 were removed immediately after recovery from the oviducal and uterine flushings and placed in $10 \mathrm{ml} \mathrm{TCM} 199$ or PBS. Half the eggs from each donor were stored in either TCM 199 or PBS in sterile glass dishes, covered by watch glasses, for $1 \frac{1}{2}-2 \mathrm{hr}$, and the rest were stored for $6 \frac{1}{2}-7 \frac{1}{2} \mathrm{hr}$ in the same medium at room temperature. The $\mathrm{pH}$ of the media used for storage was determined just before the eggs were placed in the media and immediately after removal of the eggs.

On completion of storage, eggs were transferred to the ligated oviducts of rabbits in the follicular phase (Adams, Moor \& Rowson, 1968). Day-5 eggs were left in the rabbit oviduct for $48 \mathrm{hr}$, during which time they would be expected to reach the blastocyst stage. Day-3 eggs were left in the rabbit oviduct for $96 \mathrm{hr}$ to enable them to reach the same stage of development as the Day-5 eggs (Lawson, Rowson \& Adams, 1972).

After recovery of the eggs from the rabbit oviduct, they were examined by microscopy as fresh specimens and the stage of development noted. A representative number of apparently normal blastocysts and all retarded or degenerate eggs were fixed in aceto-ethanol, stained with lacmoid and examined by phase-contrast microscopy.

\section{Experiment 2}

The cold storage of cow eggs obtained from 16 heifers on Day 5 and 6 heifers on Day 6 was examined. The eggs were transferred to $8-10 \mathrm{ml}$ PBS following recovery from the donors and within $2 \mathrm{hr}$ were placed in a small glass test-tube $(1.5 \times 5.5 \mathrm{~cm})$ containing 1-2 ml PBS alone, or PBS supplemented with $20 \%$ fetal calf serum (PBS $+20 \%$ FCS). The eggs were then either cooled rapidly $\left(>10^{\circ} \mathrm{C} / \mathrm{min}\right.$ ) by direct transfer of the tubes to a water bath at the appropriate temperature, cooled at $1^{\circ} \mathrm{C} / \mathrm{min}$ or cooled at $0.2^{\circ} \mathrm{C} / \mathrm{min}$ to final temperatures of $0^{\circ} \mathrm{C}, 2^{\circ} \mathrm{C}, 5^{\circ} \mathrm{C}$ or $7 \cdot 5^{\circ} \mathrm{C}$. The eggs were stored at these temperatures for $2 \mathrm{~min}, 30 \mathrm{~min}$ or $24 \mathrm{hr}$. Some eggs from each donor were kept at room temperature in small glass tubes for the same time as those eggs cooled and stored for $2 \mathrm{~min}$ or $30 \mathrm{~min}$. These eggs received the same treatment as cold-stored eggs except for cooling and acted as controls.

Following cold storage, the eggs were warmed by placing the tubes in a water bath at room temperature. After $20 \mathrm{~min}$ at room temperature, cooled and control eggs were transferred separately to the ligated oviducts of 'follicular phase' rabbits. The eggs were allowed to remain in the rabbit oviduct for $48 \mathrm{hr}$, and after recovery all eggs were examined as fresh specimens by microscopy to determine the stage and normality of development. The eggs were then fixed in aceto-ethanol and stained with lacmoid and examined by phase-contrast microscopy.

\section{Results}

From 21 heifers on Day 5 and 6 heifers on Day 6 in both experiments, 331 eggs were obtained; 186 were normal morulae of 32 cells or more, 74 were normal 8- to 24-celled eggs and 77 were either unfertilized, degenerate (PI. 1, Fig. 1) or were recovered as empty zonae pellucidae. Of the 244 
PLATE 1
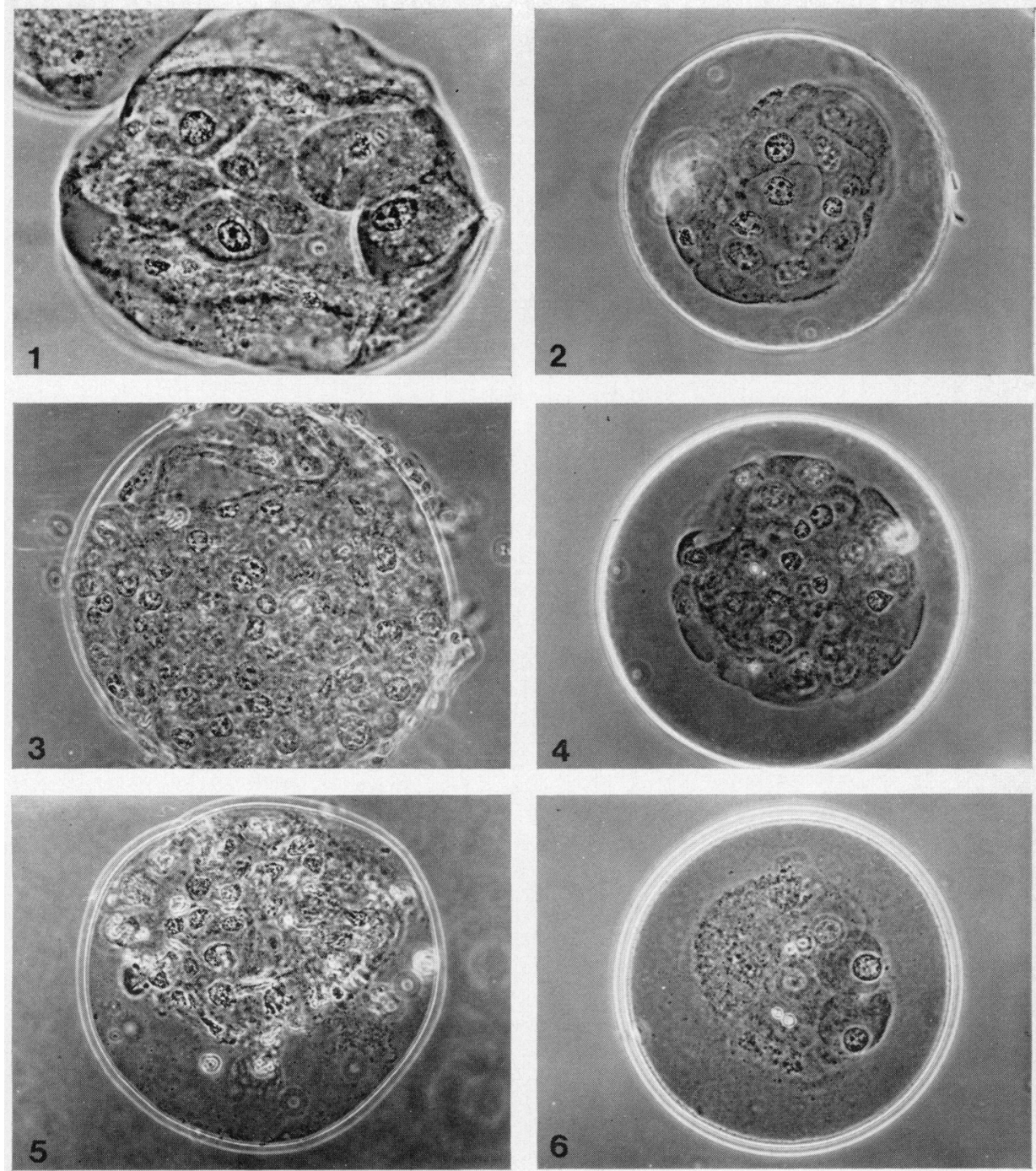

Fig. 1. A degenerate 12-celled egg obtaired frem a heifer on Da! 5. Apparently normal. degenerate and pyknotic nuclei present. Lacmoid stain, $\times 290$.

Fig. 2. A retarded morula of 38 cells after storage in TCM 199 for I! hr as a Day-3,8-celled egg and incubation for $96 \mathrm{hr}$ in a rabbit oviduct. Lacmoid stain, $\times 250$.

Fig. 3. A normal expanded blastocyst after cooling to $7.5 \mathrm{C}$ at $0.2 \mathrm{C}$ min as a Day-5 morula, storage for $30 \mathrm{~min}$ at $7.5 \mathrm{C}$ and incubation in a rabbit oviduct for $48 \mathrm{hr}$. Lacmoid stain, $\times 250$.

Fig. 4. A partly developed morula of 55 celis after cooling to $5 \mathrm{C}$ at $1 \mathrm{C}$ imin as a Day-5 morula, storage for $30 \mathrm{~min}$ at $5 \mathrm{C}$ and incubation in a rabbit oviduct for $48 \mathrm{hr}$. Some degenerate and pyknotic nuclei present. Lacmoid stain, $\times 250$.

Fig. 5. A degenerate egg after cooling to $7.5 \mathrm{C}$ at $1 \mathrm{C} / \mathrm{min}$ as a Day-6 morula, storage for $30 \mathrm{~min}$ at $7.5 \mathrm{C}$ and incubation in a rabbit oviduct for $48 \mathrm{hr}$. Lacmoid stain, $\times 250$.

Fig. 6. A degenerate egg after cooling to $2 \mathrm{C}$ at $1 \mathrm{C}$. min as a Day-5 morula, storage for 24 hr at $2 \mathrm{C}$ and incubation in a rabbit oviduct for $48 \mathrm{hr}$. Four cells and nuclei have remained intact but the other cells are disrupted and lew pyknotic nuclei remain. Lacmoid stain, $\times 250$. 
normal eggs transferred to the rabbit oviduct $212(87 \%)$ were recovered $48 \mathrm{hr}$ later. Ninety. seven normal 8-celled eggs were obtained from 10 heifers on Day 3 and a further 7 were 4- to 6-celled. Four eggs were unfertilized. Of the 828 -celled eggs transferred to rabbit oviducts, $78(95 \%)$ were recovered $96 \mathrm{hr}$ later.

\section{Experiment 1}

Neither storage time nor storage medium had any significant effect on the development of Day-5 eggs to apparently normal blastocysts (Table 1). There was no apparent difference in the numbers of normal blastocysts obtained after storage and incubation for $48 \mathrm{hr}$ of 8- to 24-celled eggs or morulae of 32 cells or more collected on Day 5. Storage time had no significant effect on the development of Day-3 eggs (Table 2) but fewer eggs developed to normal blastocysts after storage in TCM 199 than after storage in PBS (22 of 45 versus 28 of $33 ; P<0 \cdot 01$ ).

Table 1. The effect of medium and storage time at room temperature $\left(18-21^{\circ} \mathrm{C}\right)$ on the development of Day-5 cow eggs in the rabbit oviduct

\begin{tabular}{ccccc}
\hline $\begin{array}{c}\text { Storage } \\
\text { time (hr) }\end{array}$ & $\begin{array}{c}\text { Storage } \\
\text { medium }\end{array}$ & $\begin{array}{c}\text { Total } \\
\text { no. of eggs } \\
\text { treated }\end{array}$ & $\begin{array}{c}\text { Development after } 48 \text { hr in the } \\
\text { rabbit oviduct }\end{array}$ \\
\hline $\begin{array}{llll}1 \frac{1}{2}-2 \\
6 \frac{1}{2}-7 \frac{1}{2}\end{array}$ & TCM 199 & 15 & 5 & $10(66 \cdot 7)$ \\
Total & TCM 199 & 13 & 3 & $10(76 \cdot 9)$ \\
& & 28 & 8 & $20(71 \cdot 4)$ \\
$1 \frac{1}{2}-2$ & PBS & 13 & 1 & $12(92 \cdot 3)$ \\
$6 \frac{1}{2}-7 \frac{1}{2}$ & PBS & 11 & 2 & $9(81 \cdot 8)$ \\
Total & & 24 & 3 & $21(87 \cdot 5)$ \\
\hline
\end{tabular}

Table 2. The effect of medium and storage time at room temperature $\left(18-21^{\circ} \mathrm{C}\right)$ on the development of Day-3 cow eggs in the rabbit oviduct

\begin{tabular}{|c|c|c|c|c|c|}
\hline \multirow{2}{*}{$\begin{array}{l}\text { Storage } \\
\text { time (hr) }\end{array}$} & \multirow{2}{*}{$\begin{array}{l}\text { Storage } \\
\text { medium }\end{array}$} & \multirow{2}{*}{$\begin{array}{c}\text { Total } \\
\text { no. of eggs } \\
\text { treated }\end{array}$} & \multicolumn{3}{|c|}{ Development after $96 \mathrm{hr}$ in the rabbit oviduct } \\
\hline & & & No. degenerate & No. retarded & No. normal $(\%)$ \\
\hline $1 \frac{1}{2}-2$ & TCM 199 & 23 & 5 & 5 & $13(56 \cdot 5)$ \\
\hline $6 \frac{1}{2}-7 \frac{1}{2}$ & TCM 199 & 22 & 10 & 3 & $9(40 \cdot 9)$ \\
\hline Total & & 45 & 15 & 8 & $22(48 \cdot 9)$ \\
\hline $1 \frac{1}{2}-2$ & PBS & 18 & 0 & 3 & $15(83 \cdot 3)$ \\
\hline $6 \frac{1}{2}-7 \frac{1}{2}$ & PBS & 15 & 2 & 0 & $13(86 \cdot 7)$ \\
\hline Total & & 33 & 2 & 3 & $28(84 \cdot 8)$ \\
\hline
\end{tabular}

The majority of eggs obtained on Day 3 that were considered normal after incubation for $96 \mathrm{hr}$ in the rabbit oviduct were early blastocysts with little expansion of the blastocoele, whereas blastocysts derived from Day-5 eggs were generally well expanded, with detectable embryonic discs, after $48 \mathrm{hr}$ incubation. Of the Day-3 eggs recovered from the rabbit, 11/78 were morulae of 20-50 cells (PI. 1, Fig. 2) and were considered retarded. The nuclei of these eggs appeared to be normal but their potential for further development was questionable since few mitotic figures were located.

For the duration of storage, the $\mathrm{pH}$ of PBS remained constant at 7.2 but the $\mathrm{pH}$ of TCM 199 changed from $6 \cdot 85-6.95$ before storage to $7 \cdot 4-7.6$ after storage for $1 \frac{1}{2}-2 \mathrm{hr}$, and to $8 \cdot 2-8.4$ after $6 \frac{1}{2}-7 \frac{1}{2} \mathrm{hr}$ at room temperature. 


\section{Experiment 2}

The survival and development of eggs following cooling and storage are summarized in Table 3. Blastocysts of 64 cells or more with normal nuclei and mitotic figures were classed as normal (PI. 1, Fig. 3), whereas eggs of less than 64 cells with 32 or more normal nuclei and, invariably, a number of degenerate and pyknotic nuclei were termed partly developed (P1. 1, Fig. 4). Degenerate eggs contained few normal nuclei and the cell membranes of many blastomeres were disrupted (Pl. 1, Figs 5 and 6). When the cooled eggs were examined as fresh specimens immediately after warming these degenerative changes were not obvious but were readily observed after incubation of the eggs in the rabbit oviduct.

Table 3. The effect of cold storage on the development of Day 5-6 cow eggs in the rabbit oviduct

\begin{tabular}{|c|c|c|c|c|c|}
\hline \multirow[b]{2}{*}{$\begin{array}{l}\text { Storage } \\
\text { time }\end{array}$} & \multirow{2}{*}{$\begin{array}{c}\text { Storage } \\
\text { temperature } \\
\left({ }^{\circ} \mathrm{C}\right)\end{array}$} & \multirow{2}{*}{$\begin{array}{c}\text { Total } \\
\text { no. of eggs } \\
\text { treated }\end{array}$} & \multicolumn{3}{|c|}{ Development of eggs after $48 \mathrm{hr}$ in rabbit oviduct } \\
\hline & & & No. degenerate & $\begin{array}{l}\text { No. partly } \\
\text { developed }\end{array}$ & No. normal (\%) \\
\hline \multirow[t]{2}{*}{$2 \mathrm{~min}$} & 0 & 13 & 6 & $\mathbf{0}$ & $7(53 \cdot 8)$ \\
\hline & $7 \cdot 5$ & 21 & 15 & 2 & $4(19 \cdot 1)$ \\
\hline \multirow[t]{3}{*}{$30 \mathrm{~min}$} & 0 & 8 & 3 & 4 & $1(12 \cdot 5)$ \\
\hline & 5 & 17 & 13 & 1 & $3(17 \cdot 7)$ \\
\hline & $7 \cdot 5$ & 13 & 6 & 3 & $4(30 \cdot 1)$ \\
\hline \multirow[t]{3}{*}{$24 \mathrm{hr}$} & 2 & 21 & 18 & 2 & $1(4 \cdot 8)$ \\
\hline & 5 & 6 & 5 & 0 & $1(16 \cdot 7)$ \\
\hline & $7 \cdot 5$ & 11 & 6 & 1 & $4(36 \cdot 7)$ \\
\hline Control & $18-21$ & 46 & 2 & 6 & $38(82 \cdot 5)$ \\
\hline
\end{tabular}

The more rapid cooling rates tended to reduce survival and development of eggs although the differences were not significant. Cooling to $0^{\circ} \mathrm{C}$ and $2^{\circ} \mathrm{C}$ was carried out at $1{ }^{\circ} \mathrm{C} / \mathrm{min}$ or $>10^{\circ} \mathrm{C} / \mathrm{min}$ and normal development was obtained in $8 / 27$ eggs $(30 \%)$ and $1 / 15$ eggs $(7 \%)$, respectively. Cooling to $5^{\circ} \mathrm{C}$ was carried out at $1^{\circ} \mathrm{C} / \mathrm{min}$ and $4 / 23$ eggs $(17 \%)$ showed normal development. Eggs were cooled to $7.5^{\circ} \mathrm{C}$ at $1{ }^{\circ} \mathrm{C} / \mathrm{min}$ or $0.2^{\circ} \mathrm{C} / \mathrm{min}$ and normal development was obtained in $8 / 37 \mathrm{eggs}(21 \%)$ and $4 / 8$ eggs $(50 \%)$, respectively.

The inclusion of fetal calf serum in the storage medium appeared to have no beneficial effect on the development of cooled eggs. Normal development of eggs cooled to $5^{\circ} \mathrm{C}$ was obtained in $2 / 14$ eggs cooled and stored in PBS and $2 / 9$ eggs cooled and stored in PBS $+20 \%$ FCS. PBS alone was used for cooling to $0^{\circ} \mathrm{C}$ and $2^{\circ} \mathrm{C}$ and PBS $+20 \% \mathrm{FCS}$ was used for cooling to $7.5^{\circ} \mathrm{C}$ (Table 3).

Considerable variation was noted between individual replicates of the experiment; e.g. 6 eggs from two donor cows were cooled to $0^{\circ} \mathrm{C}$ at $1{ }^{\circ} \mathrm{C} / \mathrm{min}$ and stored for $2 \mathrm{~min}$ and were all recovered as apparently normal blastocysts, but eggs from the same donors failed to survive 30 min storage at $0^{\circ} \mathrm{C}$. In all other replicates, normal development never exceeded $50 \%$ of those cooled.

Raising storage temperature from $0^{\circ} \mathrm{C}$ to $7 \cdot 5^{\circ} \mathrm{C}$ had little beneficial effect on the survival and development of eggs and duration of storage appeared to have little effect (Table 3). Eggs of more advanced cleavage stages appeared to be more resistant to cooling damage. Of the 68 morulae of $\geqslant 32$ cells cooled to $7 \cdot 5^{\circ} \mathrm{C}$ or lower, 22 were recovered as normal blastocysts after incubation for $48 \mathrm{hr}$ in the rabbit oviduct, whereas only $3 / 428$ - to 24 -celled eggs developed to normal blastocysts after cooling ( $32 \%$ versus $7 \% ; P<0 \cdot 01)$.

\section{Discussion}

The results of Exp. 1 show that PBS was a more satisfactory medium for the short-term storage of cow eggs at room temperature than TCM 199. Storage of Day-3 eggs in TCM 199 caused considerable degeneration and retardation of egg development even when storage lasted only $1 \frac{1}{2}-2 \mathrm{hr}$. Day-5 eggs 
were less susceptible to damage by storage in TCM 199 and this difference may have contributed to the much higher pregnancy rate obtained by Newcomb \& Rowson (1975) after transfer to recipients of Day-5 eggs than Day-3 eggs. In their experiments eggs were flushed from donors, stored before transfer and transferred to recipients in TCM 199. The changes observed in the pH of TCM 199 during storage may have been deleterious to egg survival but Sreenan et al. (1975) found a reduction in egg survival, following transfer to recipients, with increasing storage time in TCM 199, irrespective of large or small changes in the $\mathrm{pH}$ values.

The cleavage stage of eggs obtained on Day 5 appeared to have little influence on their ability to develop to apparently normal blastocysts during incubation for $48 \mathrm{hr}$ in the rabbit oviduct. However, the development of Day-3 eggs after $96 \mathrm{hr}$ in the rabbit oviduct was less advanced than that of Day-5 eggs after $48 \mathrm{hr}$ and it was apparent that some retardation of development occurred during extended incubation. Lawson et al. (1972) similarly obtained a large number of morulae after incubation of 8-celled cow eggs for $96 \mathrm{hr}$ in the rabbit oviduct, but most of these eggs retained their potential to develop to calves on transfer to recipients. Eggs of equivalent age (Day 7) obtained from the cow are generally expanding blastocysts.

Cooling of Day-5 and Day-6 eggs to $7 \cdot 5^{\circ} \mathrm{C}$ and below caused degeneration of the majority of eggs. Sreenan et al. (1970) obtained limited cleavage in seven 4- to 8-celled eggs cooled very slowly to $10^{\circ} \mathrm{C}$ but few showed cleavage after rapid cooling. In the present experiments, survival of eggs tended to improve with lower cooling rates, and cooling rates lower than $0 \cdot 2^{\circ} \mathrm{C} / \mathrm{min}$ may give further improvement. However, in the method of freezing cow eggs described by Wilmut \& Rowson (1973) and our unpublished work, a relatively brief exposure of eggs to DMSO is necessary and, consequently, relatively rapid cooling is preferable because Whittingham \& Wales (1969) have shown that prolonged exposure of mouse eggs to the cryoprotective agent dimethylsulphoxide is toxic.

The cleavage stage of the egg appears to be an important factor in the survival of cow eggs after cooling. In the present experiment only $7 \%$ of 8 - to 24 -celled eggs survived cooling, whereas $32 \%$ of morulae consisting of $\geqslant 32$ cells developed to normal blastocysts. Wilmut et al. (1975) found only $1 / 198$ - to 16 -celled eggs survived rapid cooling $\left(10^{\circ} \mathrm{C} / \mathrm{min}\right)$ to $0^{\circ} \mathrm{C}$, but $7 / 9$ morulae (Day 6) developed to blastocysts after rapid cooling to $0^{\circ} \mathrm{C}$. It is possible that the morulae used by Wilmut et al. were more advanced than those used in the present study but even given the variation between replicates, it is clear that Day-5 and Day-6 cow eggs do not survive well after cooling and are not suitable for freezing by the present methods. We have found (unpublished) that Day- 5 and Day- 6 cow eggs fail to survive freezing after a wide variety of treatments, but early blastocysts may be frozen and thawed with reasonable success. Early blastocysts appear to be resistant to cooling damage (unpublished observations), and experiments on their storage characteristics are being undertaken.

The pre-blastocyst cow egg appears to be almost as susceptible to cooling damage as is the pig egg (Wilmut, 1972) and more susceptible than the sheep egg. Successful cooling and storage of the sheep egg at low temperatures $\left(4 \cdot 5^{\circ} \mathrm{C}-10^{\circ} \mathrm{C}\right)$ for $24 \mathrm{hr}$ (Averill \& Rowson, 1959), for up to 2 days (Moore \& Bilton, 1973) and for 5 days (Kardymowicz, Kardymowicz \& Kremer, 1966) have been reported. The reasons for the differences between these species, and between the stages of development of cow eggs, in the susceptibility to cooling damage is unknown and requires further investigation.

We thank Mr M. J. Cooper, I.C.I. Ltd, for donation of prostaglandin analogue (I.C.I. 80996); Dalgety Australia Ltd. for support of A.O.T. and to the Milk Marketing Board of England and Wales for support of S.M.W. and R.N.; Mr R. Patman for the photomicrographs; and Professor T. R. R. Mann for reading and discussing the manuscript.

\section{References}

Adams, C.E., Moor, R.M. \& Rowson, L.E.A. (1968) Survival of cow and sheep eggs in the rabbit oviduct. Proc. 6th Int. Congr. Anim. Reprod. \& A.I., Paris 1, 573-574.

Averill, R.L.W. \& Rowson, L.E.A. (1959) Attempts at storage of sheep ova at low temperatures. J. agric. Sci., Camb. 52, 392-395.

Kardymowicz, M., Kardymowicz, O. \& Kremer, M. (1966) Successful in vitro storage of sheep ova for five days. Acta biol. cracov., zool. 9, 117-119. 
Lawson, R.A.S., Rowson, L.E.A. \& Adams, C.E. (1972) The development of cow eggs in the rabbit oviduct and their viability after re-transfer to heifers. J. Reprod. Fert. 28, 313-315.

MOORE, N.W. \& Bilton, R.J. (1973) The storage of fertilized sheep ova at $5^{\circ} \mathrm{C}$. Aust. J. biol. Sci. 26, 1421-1427.

Newcomb, R. \& Rowson, L.E.A. (1975) Conception rate after uterine transfer of cow eggs, in relation to synchronization of oestrus and age of eggs. $J$. Reprod. Fert. 43, 539-541.

Rowson, L.E.A., Moor, R.M. \& LAwson, R.A.S. (1969) Fertility following egg transfer in the cow; effect of method, medium and synchronization of oestrus. J. Reprod. Fert. 18, 517-523.

Rowson, L.E.A., LAwson, R.A.S. \& Moor, R.M. (1971) Production of twins in cattle by egg transfer. J. Reprod. Fert. 25, 261-268.

Sreenan, J., Scanlon, P. \& Gordon, I. (1970) Storage of fertilized cattle ova in vitro. J. agric. Sci., Camb. 74, 593-594.
Sreenan, J.M., Beehan, D. \& Mulvehill, P. (1975) Egg transfer in the cow: factors affecting pregnancy and twinning rates following bilateral transfers. J. Reprod. Fert. 44, 77-85.

Whittingham, D.G. (1971) Survival of mouse embryos after freezing and thawing. Nature, Lond. 233, 125126.

Whittingham, D.G. \& Wales, R.G. (1969) Storage of two-cell mouse embryos in vitro. Aust. J. biol. Sci. 22, 1065-1068.

WiLmuT, I. (1972) The low-temperature preservation of mammalian embryos. J. Reprod. Fert. 31, 513514.

WILmuT, I. \& Rowson, L.E.A. (1973) Experiments on the low-temperature preservation of cow embryos. Vet. Rec. 92, 686-690.

Wilmut, I., Polge, C. \& Rowson, LE.A. (1975) The effect on cow embryos of cooling to 20,0 and $-196^{\circ} \mathrm{C}$. J. Reprod. Fert. 45, 409-411.

Received 14 May 1975 